ZESZYTY NAUKOWE UNIWERSYTETU SZCZECIŃSKIEGO

NR 884

EKONOMICZNE PROBLEMY USŁUG NR 119

2015

DOI: 10.18276/epu.2015.119-06

\author{
Ludmila Filina-Dawidowicz* \\ Mykhaylo Postan**
}

\title{
THE DIRECTIONS OF THE SERVICE DEVELOPMENT \\ OF EUROPEAN SEAPORTS SPECIALIZING \\ IN HANDLING PERISHABLE GOODS
}

\begin{abstract}
The article discusses the issues of the service development in seaports specializing in handling perishable goods. The basic service range of seaports has been presented, and the classification of services provided for perishable goods in the territory of ports' container terminals and refrigerated warehouses proposed. The challenges and main directions of the service development in the European seaports reloading perishable goods have been analyzed, too. The conducted research has showed that, in recent years, an intensive development in the group of logistics services has been observed and ports emphasize the possibility of comprehensive servicing of perishable goods.
\end{abstract}

Keywords: seaport, services, logistics, perishable goods

* Ludmiła Filina-Dawidowicz, PhD, West Pomeranian University of Technology, Faculty of Maritime Technology and Transport, Department of Logistics and Transportation Economics, e-mail address: lufilina@zut.edu.pl.

** Mykhaylo Postan, Prof., DSc, Odessa National Maritime University, Faculty of Economy and Management, Department of Management and Marketing in Marine Transport, e-mail address: postan@ukr.net. 


\section{Introduction}

Improving welfare and living standards of Europe's population leads to the growth in demand for food and increased consumption of the perishable products such as vegetables, tropical fruit, meat products, medicines, etc. According to the data by the Drewry Maritime Research (Drewry 2015), in the years 2002-2013 the worldwide trade of perishable reefer goods increased on the average by about 3.9\% per year, and in 2014 this trade reached almost 190 million tons (Fig. 1). The growth in the seaborne trade of perishable reefer goods was particularly strong in 2014, amounting to $4.9 \%$ year on year, much above the average for the last decade. Experts predict that the growth trend will continue until 2018.

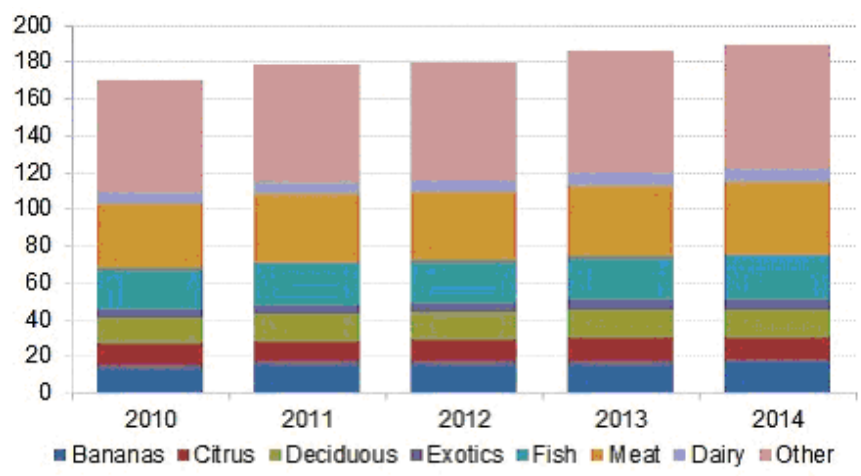

Figure 1. Worldwide perishable reefer trade

Source: Drewry Maritime Research, Reefer Shipping Market Annual Review and Forecast 2015/16, Drewry Publishing, London 2015.

For the last 20 years significant changes have been observed in the perishable goods transportation market (Klopott 2015). A large part of the perishable cargo flow has been transferred from reefer ships to container vessels carrying refrigerated containers (Arduino et al. 2015). In 1980, 33\% of perishable reefer goods were carried in containers, but in 2013 this number reached about $95 \%$. It is forecasted that the reefer capacity on the container ship fleet will continue to grow and by 2018 it will increase by $22 \%$. The number of slots for 40 -foot containers will grow from 1,6 $\mathrm{mln}$ in 2013 to $1,9 \mathrm{mln}$ slots in 2018 (Drewry 2015, Reefer). 
According to the authors of the Annual Report 2015 from the Global Container Terminal Operators published by Drewry Maritime Research, an average growth of the global container port demand by $4.5 \%$ annually is forecasted until 2019 (Drewry 2015, Annual). This translates into an increase in the container port handling by extra $168 \mathrm{mln}$ TEU bringing the global total port traffic up to $850 \mathrm{mln}$ TEU by the end of the decade. Furthermore, the market situation is accompanied by the launching of ultra large container vessels (with the capacity of 18 ths. TEU) compelling ports operators to improve containers service processes.

During the transport and storage of perishable goods it is necessary to provide certain climatic conditions (microclimate parameters: constant temperature, humidity, ventilation, etc.). Changes or failure to comply with these conditions may result in cargo quality loss or its storage time reduction (Filina and Filin 2008). Therefore, seaports' clients pay attention first of all to the safety of transported perishable goods as well as to the qualitative and reliable organization of transportation and complex cargo service from the sender to the final consumer.

The seaport service of perishable goods is executed in container terminals and port refrigerated warehouses (Container Handbook 2003). With the growth of transported cargo volume, the complexity level of cargo technological processing in ports increases, with the result that ports are constantly adapting the infrastructure and equipment of their terminals so as to safe-service the growing goods flow.

Besides the infrastructure, the maintenance of perishable goods in seaports is affected by such factors as: the organization of port functioning, used handling techniques, the turnover, access to land and waterborne transport infrastructure, used technical, technological and system solutions, etc.

The aggravated competition conditions between seaports and growing customer requirements are pushing ports to develop not only their transshipment capacity, but also improve the quality of provided services. Over the last 25 years there have been significant changes in the range and ways of the service execution intended at perishable products in seaports.

The objective of the paper is to classify services and analyse directions of their current development in the seaports specializing in the maintenance of perishable reefer goods. 


\section{Classification of seaport services}

The process of cargo- and vehicle servicing at seaports is an ordered sequence of organizational and logistical, technical and technological, economic and legal processes as well as actions and activities being part of a broadly understood cycle of goods movement going from their place of production (extraction) to the places of their consumption (processing) (Grzelakowski, Matczak 2006). All seaport services can be divided into dispositional, including planning, organization and control of all operations in the port area, as well as technical and executable, including transshipment, storage, transport within the port, qualitative and quantitative control of goods, etc. (Klimek 2009). Another classification (Szwankowski 2000) distinguishes services rendered to cargo, ships, other vehicles and passengers. ${ }^{1}$ In the literature on the subject, attention is paid to the value of a group of port logistics services playing an important role in the countries national economy and covering a wide range of services, mainly related to the cargo treatment (manipulation), logistics costs minimization and rationalization of goods distribution in the process of their moving from the sender to the recipient (Kurlyand et al. 2013).

An analysis of available sources has shown that the seaport services provided for perishable reefer goods previously are not widely described in the literature on the subject. Therefore, the authors propose to adopt the following definition of these services: "a set of organizational, technical, technological, financial, administrative and commercial processes aimed to comprehensively maintain and preserve the commodity quality of perishable reefer cargo during its stay in the port".

The authors propose to divide the seaport services, regarding perishable goods maintenance, into four groups (Table 1). Currently, the first three sets of the services form the range of services observed in the majority of seaports specializing in perishable reefer goods handling, while the assortment of the fourth group of logistics services is widely implemented in ports of the fourth and higher generations and develops intensively from year to year. The discussed services may be provided by the seaport, terminal operator or external companies specializing in specific activities for perishable goods and their transport means.

1 The further parts of this article deal mainly with services provided for cargo. 
Table 1. Classification of services related to perishable goods in seaports

\begin{tabular}{|c|c|c|}
\hline Services group & Container terminal & Refrigerated warehouse \\
\hline Basic & $\begin{array}{l}\text { - cargo overloading from/to ship, at } \\
\text { the terminal, from/to land transport } \\
\text { means } \\
\text { - storage } \\
- \text { transportation within terminal and } \\
\text { port, etc. }\end{array}$ & $\begin{array}{l}\text { - cargo overloading from/to ship, } \\
\text { at the terminal, from/to land } \\
\text { transport means } \\
\text { - storage } \\
\text { - transportation within refrigerated } \\
\text { warehouse and port, etc. } \\
\end{array}$ \\
\hline Additional & $\begin{array}{l}\text { - customs control } \\
\text { - container weighing } \\
\text { - x-ray } \\
\text { - container washing } \\
\text { - filling or emptying container, etc. }\end{array}$ & $\begin{array}{l}\text { - customs control } \\
\text { - container weighing } \\
\text { - palletizing, packaging, sorting } \\
\text { of goods } \\
\text { - cargo overloading from reefer } \\
\text { container to trailer, etc. }\end{array}$ \\
\hline Specific & $\begin{array}{l}\text { - regular monitoring of cargo storage } \\
\text { temperature } \\
\text { - refrigerated container plug in/ plug } \\
\text { off to the power supply } \\
\text { - put on/ put off portable generator } \\
\text { Gen Set to a container } \\
\text { - veterinary and phytosanitary con- } \\
\text { trol } \\
\text { - change of temperature settings, etc. }\end{array}$ & $\begin{array}{l}\text { - ensuring a needed temperature } \\
\text { of cargo storage } \\
\text { - regular monitoring of cargo dur- } \\
\text { ing storage } \\
\text { - veterinary and phytosanitary } \\
\text { control, etc. }\end{array}$ \\
\hline Logistics & \multicolumn{2}{|c|}{$\begin{array}{l}\text { - enabling to obtain detailed information by clients about the stage of cargo } \\
\text { service } \\
\text { - consulting, including calculation of customs duties, an optimized mat- } \\
\text { ching of maritime and land transport schedules } \\
\text { - distribution } \\
\text { - advertising } \\
\text { - certification and expertise } \\
\text { - cargo insurance } \\
\text { - formation of consignments } \\
\text { - vehicles hiring } \\
\text { - repair and service of reefer containers, trailers } \\
\text { - organization of multimodal transport } \\
\text { - documents execution, etc. }\end{array}$} \\
\hline
\end{tabular}

Source: own research.

The group of the basic services include first of all the operations of transshipment and warehousing, as well as cargo transportation within the port. These services are present in all ports, and are necessary for the maintenance of cargo transportation process. An important feature of perishable reefer goods warehousing is to create the necessary conditions for the storage of different types of reefer cargo according to customers' requirements as well as ensure the set temperature and humidity conditions, or else achieve and maintain an optimal level of oxygen and recommended carbon dioxide concentration.

The additional services include the operations that are carried out with a cargo according to customer specification and can be provided not only for 
perishable goods, but also other general cargo served on the considered terminals. These services include, for example, customs, weighing, palletizing etc.

The third group comprises the specific services that take into account the characteristics and specificity of perishable goods, for example, the need to plug in the container to the power supply, temperature control of cargo storage, veterinary control, putting on portable Gen Set generator to the refrigerated container during its further transportation by road transport, etc. The implementation of these services is provided by specialized staff.

An analysis of the range (assortment) of services provided in the processing of perishable goods in seaports demonstrates that over the last 25 years the logistics services group has developed intensively. This group of services includes insurance, distribution, freight forwarding, advertising, consulting, assistance in obtaining accompanying documents, etc. An increasing range in this group of services has been observed both in ports' refrigerated warehouses and container terminals. This is supported by the construction of additional warehouses and logistics centers in ports or in their surrounding focusing specialized companies, which allow ports to carry out complex cargo service.

\section{Problems of the seaport service development}

Observing the development of services provided in seaports, it can be noticed that the ports of different regions of Europe have different service range and they are implemented at a different pace. This is justified because the market determines the need and generates the demand for services. The formation of the range of services is affected by several factors such as: the geographical position of a port regarding the main trade routes and national/international transport corridors, access to transport infrastructure, volume and variety of handled perishable goods and cargo transportation direction (import/export/transit), hinterland capacity, service prices, port's ability to invest etc. and, above all, requirements of its customers. For example, a boundary veterinary control points in Portuguese ports are present only at 4 out of 6 container terminals, this being due to the fact that a significant part of the country's perishable goods trade accounts both for the export of national fruit and vegetables and trade with EU countries. ${ }^{2}$ At the same time the ports offer the ability of refrigerated containers transportation to

2 The veterinary control certificate should receive loads of animal origin imported to the EU. 
the hinterland using not only roads, but also railways, while in Poland almost all refrigerated containers are delivered to/from ports by road transport means (Kotowska 2014).

While improving both the quality of existing services and implementation of new ones, seaports are facing a number of challenges (Fig. 2).

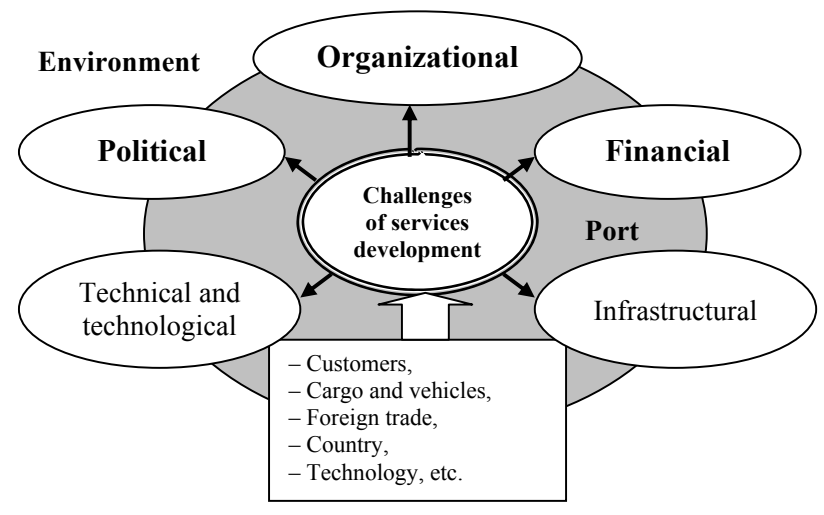

Figure 2. Development challenges of services related to perishable goods in seaports Source: own research.

One of the main challenges as regards the introduction of new services is related to the organizational activities of the port. Such problems include: bureaucracy, long-lasting decision making, difficult access to specialized companies, obstacles with information exchange between various participants involved in cargo handling in the port area, etc. The solution of these organizational issues is often supported by the implementation of information systems and technologies that improve and accelerate the processes of planning, realization and controlling the way of service performance thus contributing to the added value creation. It enables the integration not only of cargo service participants located in the port area, but also of port with external users (Pluciński 2013).

The international trade policy regarding the import, export or transit of goods, cooperation between neighboring countries, state support for domestic producers (e.g. fruit and meat products) influences ports turnover and, respectively, the demand and range of services. For example, in the early 2014 the Russian embargo on foodstuffs from EU countries affected the decrease in handling perishable goods in the ports of countries involved in the seaborne trade 
in question. Such situations lead to the fact that some of the ports are not eager to invest in the service development because of un unstable situation, for fear of incurring the expense.

Ports' technical and technological problems can result from their poor technical conditions and a low development level of the infrastructure and equipment for perishable goods maintenance. For example, a significant part of the Russian ports' refrigerated warehouses was built in the 1960s, and now they do not meet modern standards. Therefore, the effective functioning of the existing refrigerators which have not undergone modernization yet is very low, they are extremely energy-intensive and environmentally hazardous (Rikoshinskij 2011). In addition, some facilities demonstrate to be technically difficult as regards ensuring different temperature modes for various goods storage.

Moreover, the implementation of investments in services entails costs. Ports are not always in the position to finance investment projects from own sources as well as have frequent problems with accessing external financing. In such situations, ports try to encourage ports operators or private investors to join the venture and obtain funds from other sources. For example, the ports of the European Union actively strive to receive money from the specially dedicated Community funds for the development of infrastructure and technical equipment of terminals (Mańkowska 2014).

The investments carried out on container terminals and refrigerated warehouses can be related to the operational costs minimization, improvement of processes realization and expansion of current business activity etc. However, the investment introduction often results in higher service prices. Analyzing the sample service prices placed in port tariffs available on official websites of the chosen container terminals it can be seen that the prices for refrigerated containers maintenance are different depending on the size and location of the container terminal, service quality and operation time etc. (Table 2). For example, despite its high prices, the Hamburg seaport is frequently chosen by clients. Terminals often run an individual pricing policy regarding regular customers (shipping companies), furthermore, the price of port services is often regarded as an integral part of cargo transportation process (Pluciński 2013). 
Table 2. Prices for the 40-foot containers' services according to the tariffs of selected container terminals

\begin{tabular}{|c|c|c|c|c|}
\hline \multirow[b]{2}{*}{ Service } & \multicolumn{4}{|c|}{ Terminal, port, country } \\
\hline & $\begin{array}{l}\text { DCT, } \\
\text { Gdansk, } \\
\text { Poland }\end{array}$ & $\begin{array}{l}\text { Eurogate, } \\
\text { Hamburg, } \\
\text { Germany }\end{array}$ & $\begin{array}{l}\text { TCB, } \\
\text { Barcelona, } \\
\text { Spain }\end{array}$ & $\begin{array}{c}\text { VCT } \\
\text { Vladivostok, } \\
\text { Russia** }^{* *}\end{array}$ \\
\hline $\begin{array}{l}\text { Container overloading } \\
\text { to/from ship [EUR ] }\end{array}$ & 36 & 260 & $\begin{array}{c}\text { Import/export: } \\
143 ; \\
\text { Transit: } 72\end{array}$ & $\begin{array}{l}\text { Export: } 39 ; \\
\text { Import: } 102\end{array}$ \\
\hline $\begin{array}{l}\text { Storage } \\
\text { [service days: EUR/day] }\end{array}$ & $\begin{array}{c}\text { 6-14: } 8 \\
\text { 15-30: } 10 \\
\text { 31-60: } 20 \\
\text { Next from } \\
\text { 61: } 40\end{array}$ & $\begin{array}{c}\text { Import: } \\
\text { 4-8: } 105 ; \\
\text { 9-13: } 210 ; \\
\text { 14-18: } 315 ; \\
\text { Next from 19: } \\
\text { 420. } \\
\text { Export: } \\
\text { 4-11: } 105 ; \\
\text { Next from 12: } \\
\text { 210. } \\
\text { Transit: } \\
\text { 4-11: } 105 ; \\
\text { Next from } 12 \text { : } \\
\text { 210 }\end{array}$ & $\begin{array}{c}\text { Import/export: } \\
\text { 6-7: 4; } \\
\text { 8-14: } 10 ; \\
\text { 15-21: } 20 \\
22-28: 30 \\
29-42: 40 \\
\text { Next from 43: } \\
80 . \\
\text { Transit: } \\
\text { 15-28:4 } \\
\text { Next from } 29 \text { : } \\
10\end{array}$ & $\begin{array}{c}\text { 8-14: } 59 \\
\text { 15-25: } 80 \\
\text { Next from } \\
\text { 26: } 99\end{array}$ \\
\hline $\begin{array}{l}\text { Receiving and delivery of } \\
\text { container by truck [EUR] }\end{array}$ & 36 & 104 & $\begin{array}{c}\text { Import/export: } \\
56 ; \\
\text { Transit: } 15\end{array}$ & 44 \\
\hline $\begin{array}{l}\text { Plug on/ plug off the } \\
\text { container to power supply } \\
\text { [EUR/ } 2 \text { operations] }\end{array}$ & $17^{*}$ & $\begin{array}{l}1 \text { day: } 127 \\
\text { Next days: } 101\end{array}$ & 51 & 51 \\
\hline $\begin{array}{l}\text { Cooling and monitoring } \\
\text { [EUR/ day] }\end{array}$ & $26^{*}$ & & & \\
\hline $\begin{array}{l}\text { Change of temperature } \\
\text { settings [EUR] }\end{array}$ & $-{ }^{* * *}$ & 49,5 & - & - \\
\hline $\begin{array}{l}\text { Put on/ put off the GenSet } \\
\text { generator [EUR/ day] }\end{array}$ & $17^{*}$ & - & - & - \\
\hline $\begin{array}{l}\text { Move for X-ray } \\
\text { [EUR/ cont.] }\end{array}$ & $99^{*}$ & 429 & - & 134 \\
\hline $\begin{array}{l}\text { Move for overview or } \\
\text { inspection [EUR/ cont.] }\end{array}$ & $99^{*}$ & $\begin{array}{l}162 \\
430 \text { (to veteri- } \\
\text { nary authority) }\end{array}$ & 31 & 203 \\
\hline Container weighing & $78^{*}$ & - & - & 176 \\
\hline $\begin{array}{l}\text { Filling or emptying con- } \\
\text { tainers, including } \\
\text { the stowage }[\mathrm{EUR} / \mathrm{t}]\end{array}$ & $12^{*}$ & - & $\begin{array}{l}\text { Non-pallet: } \\
\text { 20,5; } \\
\text { Pallet: } 8\end{array}$ & $\begin{array}{l}753 \\
\text { (for a con- } \\
\text { tainer) }\end{array}$ \\
\hline
\end{tabular}

Source: own research as based on DCT 2015, Eurogate 2015, TCB 2015, VCT 2015. 
Infrastructural port problems are associated mainly with the limited space in ports or adjacent area (e.g. the space needed for additional service introduction), lack of storage facilities, poor quality of infrastructure of port's and access to hinterland, etc. In some ports (eg. Il'ichevsk, Szczecin) the storage area for refrigerated containers is far from the quay thus requiring moving the containers by the port platforms across the port territory. This infrastructure arrangement influences not only the container service time, but, primarily, the time of its disconnection from the power supply. In some ports (e.g. Odessa, Leixoes) there is a limited space for the refrigerated containers storage. Refrigerated containers are deployed in the 3-4 rows close to each other. As a result, in order to obtain the container from the lower tier, the execution of a number of additional loading and unloading operations related to the rearrangement of containers in higher tiers is needed. In addition, such a limited space contributes to emergencies with port machinery and containers damage (Filina-Dawidowicz, Postan 2013).

\section{Actual directions of the service development}

The conducted analysis has showed that the main development directions of the seaport services specializing in maintenance of perishable goods include:

- improving the quality of cargo service, dealing with the reduction of maintenance time and risk minimization of cargo damage within the port,

- expansion of services package (assortment), including development of logistics services group within the port and its immediate environment (the construction of warehouses and logistic centers near the port),

- comprehensive customer service.

The quality of ports' services is significantly determined by the efficiency of information, material and financial resources flow, which in turn depends on the means and methods of the organization and management of individual processes executed in ports (Grzelakowski, Matczak 2006). Improving the perishable goods service quality processing is associated primarily with the port operation rates and an increase in the cargo safety level. ${ }^{3}$

The drive towards reducing the time of the port cargo service has been observed in almost all leading European ports. The time of the perishable goods

3 The issue of cargo service quality includes: speed, mass, availability, reliability, security in terms of trouble-free operation and the lack of damage to goods and transport means, etc. (Grzelakowski, Matczak 2006). 
processing in ports depends on various factors including the infrastructure location, type and state of handling equipment, size of the serviced vessels and delivered cargo, efficiency of land transport, port mode, staff competences, weather conditions etc. In order to reduce the maintenance time ports invest primarily in handling equipment, expand their storage capacity, automate the processes of cargo movement within the terminals and improve related documents execution, analyze the delays in order to optimize the performing process for separate operation of goods service (e.g., Hamburg and Rotterdam). But the time of the cargo stay in port does not always depend solely on the port. It happens that customers do not want to collect the goods quickly, using the possibility of cargo temporary storage. Ports do their best to limit such situations by appropriately prepared tariffs (Tab-le 2) that motivate freight owners and forwarders to removing containers from the terminal faster.

The reduction of the perishable goods service time is also affected by a number of organizational decisions, including merge of several port operations, e.g. carrying out customs and veterinary control within a single process. This allows not only to accelerate the process, but also improve the quality of cargo service (e.g. decrease the time of container's disconnection from the power supply, as well as container's door opening).

In order to minimize the risk of perishable cargo quality loss within the port, the refrigerated container must be permanently plugged in to the power supply, and the time of its disconnection should be as short as possible. The European ports are used to controlling the temperature inside the container every 4 hours. Some ports (e.g, German, Portuguese) invest in electronic systems enabling transfer and registration of data concerning cargo storage temperature. This allows to execute the constant monitoring of temperature inside the container, and to react quickly and make appropriate decisions if any changes happen.

The expansion of the service range plays an important role in the port competition. The ability to prepare a quickly refrigerated container so as to deploy new cargo (e.g. check the technical parameters of the refrigeration unit, cleaning and washing of container, precool to the required temperature) as well as help with documents and customs can be an essential argument for choosing a particular container terminal. ${ }^{4}$

4 For example, Hamburg seaport has wide offer for containers maintenance, including sealing and resealing, labeling, outside cleaning, masking minor damages, visual documentation making (provision of photographs) etc. (Eurogate 2015). 
Ports are systematically expanding the assortment of their services, and sometimes offer even modules/packages of services. Particular attention should be focused on the development of logistics services for perishable goods (Table 1). Some ports' refrigerated warehouses orient their development towards advertising services and products distribution to a city nearby and its surroundings. Moreover, among the logistics services, consulting, including the assistance in planning goods deliveries, carrying out traffic and transportation costs calculations with the use of mathematical modeling methods has been growing in popularity.

The implementation of the customer-integrated service in a seaport is part of this port's promotional strategy considered to be a link within intermodal transport chains. It is associated with the requirements of market participants as regards complex service that enables them to deal with many transactions in one place (afforded by one operator). Creating a comprehensive package of logistics services depends on orders, i.e. the demand for certain services. This concept allows for arranging appropriate logistics processes in ports, improving the cooperation between different service providers, integrating and coordinating the physical movement of goods, information and funds. For these purposes the operator must possess a wide information network compatible with clients and other transport chain participants.

\section{Summary}

The conducted research has shown that due to the forecasted growth of the perishable cargo transportation by maritime transport means seaports adapt to the incising cargo traffic. Apart from enhancing their handling capacity, introducing innovative handling and information technologies, ports undertake the investment activity so as to improve the quality and range of services (including logistics services) for perishable goods in container terminals area and port refrigerated warehouses.

The implementation of the concept of the integrated logistics service is a promising development direction within ports specializing in the perishable reefer goods service. This approach facilitates the integration of the producers, suppliers and consumers in a single logistics system, the improvement and adaptation of seaport offers to the expectations of their customers as well as the adjust- 
ment of ports' flexibility to market demands and the enrichment of the port offer with value-added services. Finally, all these activities enable strengthening and increasing seaports competitiveness level.

\section{References}

Arduino G., D.C. Murillo, F. Parola, Refrigerated Container Versus Bulk: Evidence from the Banana Cold Chain, "Maritime Policy \& Management” 2015, No. 42 (3).

Container Handbook. Cargo Loss Prevention Information from German Marine Insurers, GDV, Berlin 2003.

Drewry Maritime Research, Annual Report 2015, Global Container Terminal Operators, Drewry Publishing, London 2015.

Drewry Maritime Research, Reefer Shipping Market Annual Review and Forecast 2015/16, Drewry Publishing, London 2015.

Filina-Dawidowicz L., M. Ya. Postan, Wptyw infrastruktury portów morskich na organizację obstugi ładunków szybko psujacych się, in: Transport $w$ regionie Pomorza Zachodniego, eds. I.N. Semenov, A. Wiktorowska-Jasik, Wydawnictwo Uczelniane ZUT w Szczecinie, Szczecin 2013.

Filina L., S. Filin, An Analysis of Influence of Lack of the Electricity Supply to Refer Containers Serviced at Sea Ports on Storing Conditions of Cargoes Contained in Them, "Polish Maritime Research", 2008, No. 4.

Grzelakowski A.S., M. Matczak., Ekonomika i zarzadzanie przedsiębiorstwem portowym. Podstawowe zagadnienia, Wydawnictwo Akademii Morskiej w Gdyni, Gdynia 2006.

Klimek H., Wartość dodana w procesie produkcji ustug portowych, „Studia Gdańskie”, Gdańska Wyższa Szkoła Humanistyczna, 2009, Vol. VI.

Klopott M., Tendencje na rynku morskich przewozów ładunków chłodzonych i ich wpływ na chłodnicze łańcuchy dostaw, Prace Naukowe Uniwersytetu Ekonomicznego we Wrocławiu, 2015, No. 382.

Kotowska I., The Analysis of Hinterlands of Intermodal Terminals in Polish Seaports. 6th International Conference on Maritime Transport, Barcelona, January 2014.

Mańkowska M., Instrumenty finansowe Unii Europejskiej jako narzędzie wspierania rozwoju polskich portów morskich na przykładzie zespołu portowego Szczecin-Świnoujście, Zeszyty Naukowe Uniwersytetu Szczecińskiego, Problemy Transportu i Logistyki No. 28, Uniwersytet Szczeciński 2014.

Pluciński M., Polskie porty morskie w zmieniającym się otoczeniu zewnętrznym, Wydawnictwo CeDeWu, Warszawa 2013.

Szwankowski S., Funkcjonowanie i rozwój portów morskich, Wydawnictwo Uniwersytetu Gdańskiego, Gdańsk 2000. 
Kurlyand A.M., M. Ya. Postan, I.V. Savel'eva., Analiz sovremennyh tendencij razvitija portov $v$ sisteme smeshannyh perevozok, in: "Rozvytok metodiv upravlinnja ta gospodariuvannja na transporti", Odeskij Nacionalnyj Morskyj Universytet, Odesa 2013, No. 4 (45).

Rikoshinskij A., Rynok uslug skladov-holodilnikov morskih portov, "Logistika”, Moskva 2011, No. 3.

http://content.portdebarcelona.cat/cntmng/d/d/workspace/SpacesStore/bf3a0556-438a4e9a-896c-81c80533486c/en.TMAXCont2011.pdf , 2015 - TCB, Barcelona seaport, prices and service conditions.

http://dctgdansk.pl/upload/files/taryfa-standardowa-dct-gdansk-2015.pdf , 2015 - DCT, Gdańsk seaport, prices and service conditions.

www.fesco.ru/clients/schedule, 2015 - VCT, Vladivostok seaport, prices and service conditions.

www1.eurogate.de/zh/.../3/.../Preisliste_CTH_EN_2014+08+01.pdf, 2015 - Eurogate Container Terminal, Hamburg seaport, prices and service conditions.

\section{KIERUNKI ROZWOJU USŁUG EUROPEJSKICH PORTÓW MORSKICH SPECJALIZUJĄCYCH SIĘ W OBSLUDZE LADUNKÓW SZYBKO PSUJĄCYCH SIE}

\section{Streszczenie}

W artykule poruszono problematykę rozwoju usług świadczonych w portach morskich, specjalizujących się w obsłudze ładunków szybko psujących się. Przedstawiono podstawowy zakres usług świadczonych w portach morskich, zaproponowano klasyfikację usług przeprowadzanych w procesie obsługi ładunków szybko psujących się na terenie terminali kontenerowych i chłodni portowych. Przeanalizowano problemy i główne kierunki rozwoju usług w europejskich portach morskich, obsługujących ładunki szybko psujące się. Przeprowadzone badania wykazały, że w ostatnich latach w tych portach obserwowany jest intensywny rozwój w grupie usług logistycznych, a porty morskie w celu podniesienia poziomu konkurencyjności podkreślają swoje przystosowanie do kompleksowej obsługi ładunków szybko psujących się.

Słowa kluczowe: port morski, usługi, logistyka, ładunki szybko psujące się 